\title{
DENETIMMDE KALİTE GÜVENCE SİSTEMİNE YÖNELİK KARMA MODEL: ALMANYA ÖRNEĞİ
}

\author{
MIXED MODEL FOR THE QUALITY ASSURANCE IN AUDIT: \\ GERMANY CASE
}

\section{Çağla Ersen Cömert*}

\section{Öz}

Dünyada bağımsız denetim faaliyetlerinde kalitenin sağlanmasına yönelik ulusal ve uluslararası boyutta pek çok önlem alınmakta ve yeni uygulamalara yer verilmektedir. 2014 yılında güncellenerek yayınlanan $\mathrm{AB}$ 8. Yönergesiyle bağımsız denetimlerde kalite güvence sisteminin güçlendirilmesi adına yeni düzenlemeler gündeme getirilmiştir. Almanya da AB üyesi bir ülke olarak, 2016 yılında yönergedeki bu değișiklikleri kendi ulusal mevzuatına aktarmış ve kalite güvence sistemine ilişkin yeni düzenlemeleri hayata geçirmiştir. Çalışma kapsamında söz konusu bu yeni düzenlemeler çerçevesinde oluşan kalite güvence sistemi incelenecektir.

Anahtar Kelimeler: Kalite güvence sistemi, kalite kontrol sistemi, bağımsız denetimde kalite.

\begin{abstract}
Many measures are being taken at the national and international level to ensure the quality of independent audit activities in the World. New regulations have been introduced to strengthen the quality assurance system in the independent audits with the EU 8 Directive updated and published in 2014. Germany, as an EU member country, transfers these amendments in the directive to its national legislation in 2016 and has passed new regulations on the quality assurance system. In the scope of the study, the quality assurance system will be examined in the framework of these new regulations.
\end{abstract}

Keywords: Quality assurance system, quality control system, audit quality.

\footnotetext{
* Doç. Dr., Marmara Üniversitesi, İşletme Fakültesi, Almanca İsletme Bölümü, caglaersen@yahoo.com, caglaersen@marmara.edu.tr
} 


\section{Giriş}

Bağımsız denetimde kalitenin sağlanmasına ilişkin gerek ulusal gerekse uluslararası alanda pek çok düzenleme yapılmakta ve bağımsız denetim faaliyetlerinde kaliteyi artırmaya yönelik önlemler alınmaktadır. Bağımsız denetim faaliyetlerinde kalite dendiği zaman akla gelen, bağımsız denetim faaliyeti sonucunda varılan görüşün ne derece isabetli ve güvenilir olduğudur. İşletme yöneticileri, tüm finansal tablo kullanıcılarına (mevcut ve potansiyel yatırımcılarına, bankalara, kredi kuruluşlarına, müşterilere, tedarikçilere vb.) finansal tablolar aracılı̆̆ıyla sundukları bilgilerin doğru, dürüst ve güvenilir nitelikte olduğunu ifade etmek için bağımsız bir güvence mekanizmasına ihtiyaç duymaktadır. Benzer şekilde bankalar, kredi kuruluşları ya da işletme hakkında bilgi ihtiyacı içinde olan diğer üçüncü taraflar da işletmenin sunduğu finansal bilgilerin doğruluğu hakkında emin olmak istemektedirler. Tüm bu ifade edilen hususlar, denetim faaliyetlerinde "kalite" kavramını - pek çok diğer hizmetteki kalite anlayışından daha fazla olarak - ön plana çıkarmaktadır. Bağımsız denetim faaliyetlerinin nitelikli, diğer bir ifadeyle kaliteli yürütülmesinin önemi ya da tam tersi ifadeyle "kalitesiz" denetim faaliyetlerinin sonucunu Enron, Wordlcom vb. krizlerin piyasalar üzerinde yarattığı yıkıcı etkilerinde gözlemlemek mümkündür. Denetimde kalitesizliğin maliyeti, bir domino etkisiyle tüm ekonomi üzerinde olumsuz izler bırakmaktadır.

Son yıllarda başta $\mathrm{ABD}$ olmak üzere pek çok ülke, bağımsız denetimde kalitenin sağlanmasına ilişkin mevzuatlarında güncellemeler yapmıştır. Bir AB üyesi olan Almanya da, özellikle AB Yönergelerinde yapılan değişiklikler çerçevesinde, kendi ulusal mevzuatını güncellemekte ve denetim alanında yeni düzenlemelere yer vermektedir. En son $A B$ 8. Yönergesi’ndeki değişikliklere paralel olarak 2016 yılında çıkarılan Denetçi Gözetimi Reform Yasası (Abschlussprüferaufsichtsreformgesetz APAReG) Almanyadaki denetim mesleğinin yapılandırılmasına ilişkin önemli yenilikler getirmiştir. Bağımsız denetimde kalitenin sağlanmasına yönelik pek çok yeni düzenleme içeren bu yasayla birlikte bağımsız denetimde kalite güvence sistemi son halini almıştır. Çalışmada, Almanyada söz konusu yasa değişiklikleri çerçevesinde oluşan Kalite Güvence Sistemi modeli açıklanarak, Türkiye'deki mevcut sistemle arasındaki benzerlik ve farklılıklar ele alınacaktır.

\section{Almanya'da Ana Hatlarıyla Denetim Mesleği}

Almanyada denetimmesleği Wirtschaftsprüferadıverilen meslekmensuplarıtarafından yürütülmektedir. Yasal zorunlu bağımsız denetimleri yapmakla yükümlü olan denetçilere ise "Abschlussprüfer" denmektedir. Almanya’da yasal zorunlu bağımsız denetimler Alman Ticaret Kanunu Madde 316 da düzenlenmiştir. Buna göre KAYİK niteliği taşıyan ve KAYİK olmamakla birlikte büyük ölçekli şirket tanımına giren işletmeler yasal olarak zorunlu bağımsız denetime tabidir. Wirtschaftsprüfer kavramı "Denetçi", Abschlussprüfer kavramı ise "Bağımsız Denetçi” şeklinde Türkçeleştirilebilir. Denetim mesleğinin şekillenmesinde rol oynayan yasa ve kurumlar ise şu şekildedir:

- Denetçi Meslek Yasası (Gesetz über eine Berufsordnung der Wirtschaftsprüfer / Wirtschaftsprüferordnung - WPO)

- Denetçiler Odası (Wirtschaftsprüferkammer - WPK) 
- Denetçiler Enstitüsü (Institut der Wirtschaftsprüfer - IDW)

- Bağımsız Denetçi Gözetim Kurumu (Abschlussprüferaufsichtstelle-APAS)

Denetçi Meslek Yasası (WPO); 1961 yılında çıkarılan ve denetçi mesleğine (denetçi ve denetim şirketleri) yönelik düzenlemelere yer veren kanundur. Ayrıca, Denetçiler Odası'nın kurulmasına, faaliyet ve denetimlerine ilişkin esasları içermektedir. Denetçiler Odası (WPK); üyeleri denetçiler, bağımsız denetim şirketleri ve muhasebe şirketleri olan tüzel kişiliğe sahip kamu kurumu niteliğinde bir meslek kuruluşudur. Odanın görevleri arasında;

- denetçi sınavlarının gerçekleştirilmesi,

- denetçilerin atanması,

- denetim mesleğinin icrasına yönelik düzenlemelere yer veren tüzük ve yönergelerin hazırlanması,

- mesleğin kamuya karşı temsil edilmesi,

- meslek mensupları arasındaki anlaşmazlıkların çözümlenmesi

sayılmaktadır. Denetçiler Enstitüsü (IDW), denetçileri ve bağımsız denetim kuruluşlarını aynı çatı altında toplamayı hedefleyen, denetim mesleğinin gelişimi için çalışmalar yürüten ve kar amacı gütmeyen bir dernektir. Merkezi Düsseldorf'da bulunmaktadır. Denetçiler Enstitüsü; denetim mesleğinin ulusal ve uluslararası platformda çıkarlarının korunması, denetçilerin sürekli eğitiminin sağlanması ve günlük çalışmalarında denetçilere destek olmak gibi görevleri üstlenmektedir. 30.06.2017 tarihi itibari ile 13.034 düzenli üyesi bulunmaktadır. Bunun 11.952 tanesi denetçi ve 1.082 tanesi bağımsız denetim şirketidir. Denetçi Gözetim Kurumu (Abschlussprüferaufsichtstelle-APAS), denetim faaliyetlerinde, meslek yapılanmasından bağımsız üst gözetim yapmak üzere kurulan ve Meslek Odası'nın faaliyetlerini inceleme görev ve yetkisine haiz kamu kurumudur. 2005 yılında Denetçi Gözetim Komisyonu adı altında kurulmuş, ancak 2016 yılında AB 8. Yönergesi’nde yapılan değişikliklere uyum amacıyla, görev ve yetki kapsamında değişiklikler yapıldıktan sonra Denetçi Gözetim Kurumu adı altında yeniden yapılandırılmıştır.

Almanyada denetim mesleğinin örgütsel bir yapıya kavuşması ve bu yapı çerçevesinde denetim faaliyetlerinin yürütülmesinde, yukarıda açıklanan yasa ve kurumlar belirleyici rol oynamaktadır. Denetim faaliyetine ilişkin her türlü düzenleme Denetçi Meslek Yasası'nda yer almakta, Avrupa Birliği Yönergeleri çerçevesinde söz konusu kanun sıklıkla güncellenmektedir. 2016 yılında çıkarılan Denetçi Gözetimi Reform Yasası, Denetçi Meslek Yasası'nda ve Denetçi Gözetim Kurumu’nun görev kapsamında değişiklikler yapmış, bağımsız denetimde kalitenin sağlanmasına ilişkin güncel uygulamaları hayata geçirmiştir.

\section{Almanya'da Denetimde Kalitenin Sağlanmasına İlişkin Sistem}

Almanyada denetimde kalitenin güvence altına alınması için oluşturulan sistemi iç önlemler ve dış önlemler olmak üzere iki grupta ele almak gerekmektedir (bkz. Şekil 1). 


\section{Denetimde Kalitenin Sağlanmasına İlişkin Sistem}
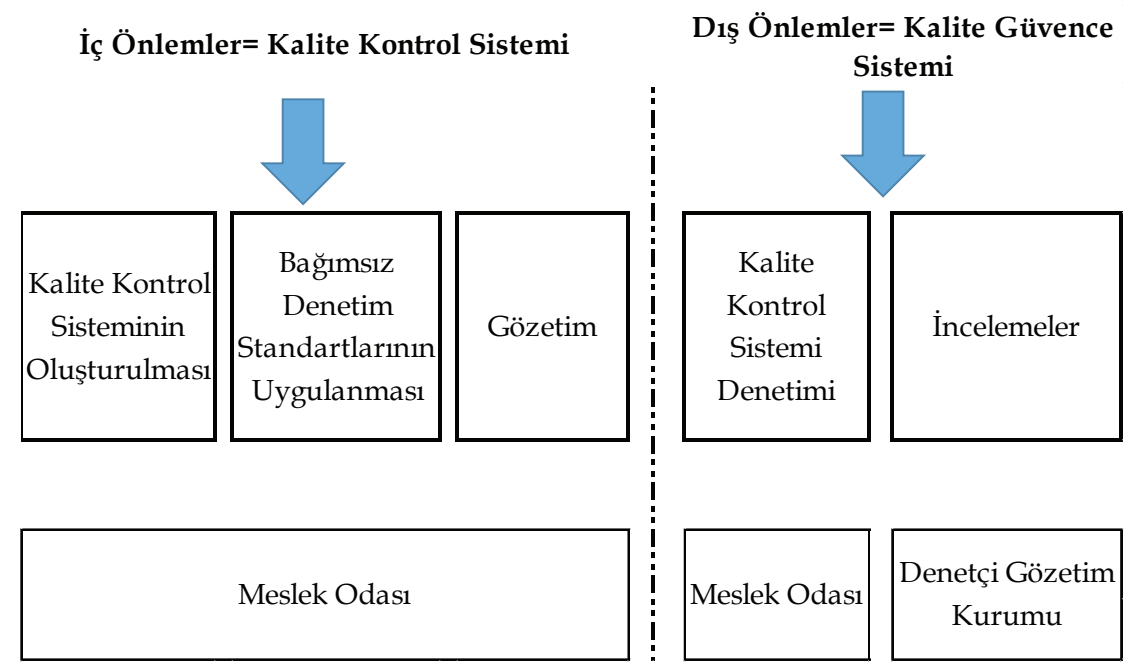

Şekil I: Almanya'da Denetimde Kalitenin Sağlanmasına İlişkin Sistem

Kalitenin sağlanmasına ilişkin iç önlemler; meslek mensuplarının denetimde gerekli kaliteyi sağlamak amacıyla, Meslek Odası düzenlemelerine uygun olarak bünyelerinde oluşturacakları sistemi ifade etmektedir. Bir kalite kontrol sistemi oluşturarak, bu sistem çerçevesinde bağımsız denetim standartlarını uygulamak ve sonrasında sistemin işlerliğini gözlemlemek meslek mensuplarının yükümlülüğüdür. Denetim işinin beklenen kalitede olabilmesi için meslek mensupları görevlerini ifa ederken bu yükümlülüklerini yerine getirerek hareket etmelidir. Kalite kontrol sistemi oluşturma, mesleki etik ve ilkelere uyma, standartların ön gördügü şekilde planlama, yürütme, raporlama gibi tamamen meslek mensubunun faaliyetlerini yürütürken göz önüne alacağı, kalitenin sağlanmasına ilișkin tedbirler kalite güvence sisteminin ilk adımıdır. Meslek mensubu denetim işini planlarken, yürütürken, raporunu hazırlarken kalitenin güvence altına alınmasını sağlamak adına Meslek Yasası ve Tüzükte yer alan tüm söz konusu düzenlemeleri uygulamak zorundadır.

Oluşturulacak kalite kontrol sisteminin bir parçası olarak kabul edilebilecek Gözetim (Nachschau) mekanizması 2016 yılında yürürlüğe girmiştir. Meslek Yasası̉nda yapılan bir değişiklikle, tüm meslek mensuplarına oluşturdukları kalite kontrol sistemini yılda bir kez inceleme (gözetim) ve bunun hakkında bir rapor hazırlama yükümlülügü getirilmiştir. Bu gözetim yükümlülüğü, meslek mensubuna yılda bir kere tüm kalite kontrol sisteminin gözden geçirilmesi fırsatı sunmaktadır. Meslek mensubu, yılın sonunda kendi denetim faaliyetlerine katılmamış, alanında uzman bir kişiye (meslek mensubu olma zorunluluğu yoktur), yıl içinde yapılan denetimlerden örneklem yoluyla belirlenenleri inceleterek, iç kalite kontrol sisteminin işlerliği hakkında rapor hazırlatmaktadır. $\mathrm{Bu}$ inceleme işini yapacak kişinin kesinlikle meslek mensubunun denetimlerine iştirak etmemiş 
olması şarttır. Meslek mensubu kalite kontrol sistemini güvence altına almak amacıyla bu inceleme için birini istihdam edebilir, bu incelemeyi dışarıdan başka bir meslek mensubuna yaptırabilir. Yıl içinde yapılan tüm denetimlerden ne kadarının inceleneceği konusunda, incelemeyi yapan kişi mesleki yargısını kullanacak, yıl içinde yapılan tüm denetimlerin sayısına uygun ölçüde incelemeler için bir örneklem kütle belirleyecektir. Bir meslek mensubunun denetim alanındaki başka bir çalışan tarafından incelenmesi söz konusu olduğu için bu uygulama Peer Review (PR) uygulamasına benzetilmektedir. PR, muhasebe ve denetim firmalarının kalite kontrol sistemlerine uyup uymadıklarının başka denetçiler tarafından incelenmesidir. Peer aynı, eşit, akran anlamına gelmektedir. Peer Review ise eşiti-akranı tarafından incelenmek anlamına gelmektedir. PR programı ile denetim firmasının kalite kontrol unsurlarına sahip olup olmadığı ve bunları uygulamada ne ölçüde yerine getirdiğinin belirlenmesi ve rapor edilmesi sağlanmaktadır (Uzay, 2006, s.13). Bu iç gözetim mekanizması, bir meslek mensubunun alanında uzman başka bir uygulayıcı tarafından iç kalite kontrol sisteminin incelemesi ve sistemin işlerliği hakkında görüş bildirmesi olduğu için bir Peer Review uygulamasıdır.

\section{Kalite Güvence Sisteminde Karma Model}

Almanya'da denetimde kalitenin sağlanmasına ilişkin yürütülen uygulamaların diğer bölümü dış kalite kontrol uygulamalarıdır. Dış kalite kontrol uygulamaları, kalite kontrol sistemiyle ulaşılmak istenen kalitenin güvence altına alınması amacıyla bağımsız, dışarıdan bir uzman tarafından yapilan incelemelerdir. Denetim faaliyetlerinin kaliteli şekilde yürütülmesi için oluşturulan kalite kontrol sisteminden sonra, bu sistemin beklenen kaliteyi sağlayıp sağlamadığına ilişkin yapılan incelemeler kalite güvence sistemini oluşturmaktadır. Meslek mensubunun süreçlerinin, sistemini hiç tanımayan bir kişi tarafından anlaşılabilecek şekilde yürütülüp çalışma kağıtlarına aktarılmış olması, denetimin kalitesi hakkında en sağlıklı görüşü oluşturacak uygulamadır.

2005 yllında Alman Denetçi Gözetim Komisyonu’nun kurulmasıyla birlikte Kalite Güvence Sistemi’nin önemli bir faktörü olarak "Monitoring" sistemi Almanyàda devreye girmiştir. Denetim alanında en önemli reform hareketi sayılan, 2004 yllındaki Denetçinin Gözetimi Kanunu’nun yürürlüğe girmesiyle birlikte Monitoring uygulamalarının yasal zemini oluşmuştur. Bu reform hareketinin temelinde; Denetçi Meslek Odası’ndan bağımsız bir üst gözetim komisyonu oluşturarak, o güne kadar Meslek Odası tarafından üstlenilmiş mesleki gözetime yönelik tüm önlem ve sorumlulukların oluşturulacak bu komisyona yüklenmesi hedefi yatmaktadır. $\mathrm{Bu}$ kanunla birlikte 2005 yılında kurulan Alman Denetçi Gözetim Komisyonu, denetim mesleğinin gözetimine yönelik kurulan ve sistemin bütününü gözleyen en üst sorumlu ve karar merciidir. Avrupa Birliği 8. Yönergesinin 2014 yllında revize edilen halinde, KAYİK denetimlerini yapan denetçilerin Meslek Odasından tamamen bağımsız bir kurum tarafından gözetime tabi tutulması öngörülmektedir. Bu düzenlemeye uyum amacıyla 2016 yllında yapılan değişikliklerle, üst gözetim mercii Alman Denetçi Gözetim Kurumu (Abschlussprüederaufsichtsstelle-APAS) adı altında yeniden yapılandırılmış ve KAYİK denetimlerini yapan bağımsız denetçilerin gözetimi doğrudan Kurum’un yetki ve sorumluluğuna verilmiştir. Kurum, Meslek Odası̉ndan tamamen 
bağımsızdır. Alman Denetçi Gözetim Kurumu, sadece denetim mesleğinde kalite kontrollerinin değil, sisteminin bütününü (denetçi seçimi, denetçi olarak atanabilme vb.) gözlemleyen bir üst kurumdur. Denetçi Gözetim Kurumu, Denetçiler Odası (WPK)'nın görevlerini uygun şekilde yerine getirip getirmediğinin gözetimini üstlenmektedir. 2016 yılı itibariyle Almanya'da uygulanan denetim mesleğine yönelik Üst Gözetim (Monitoring) sistemi Şekil 2'deki hali almıştır.

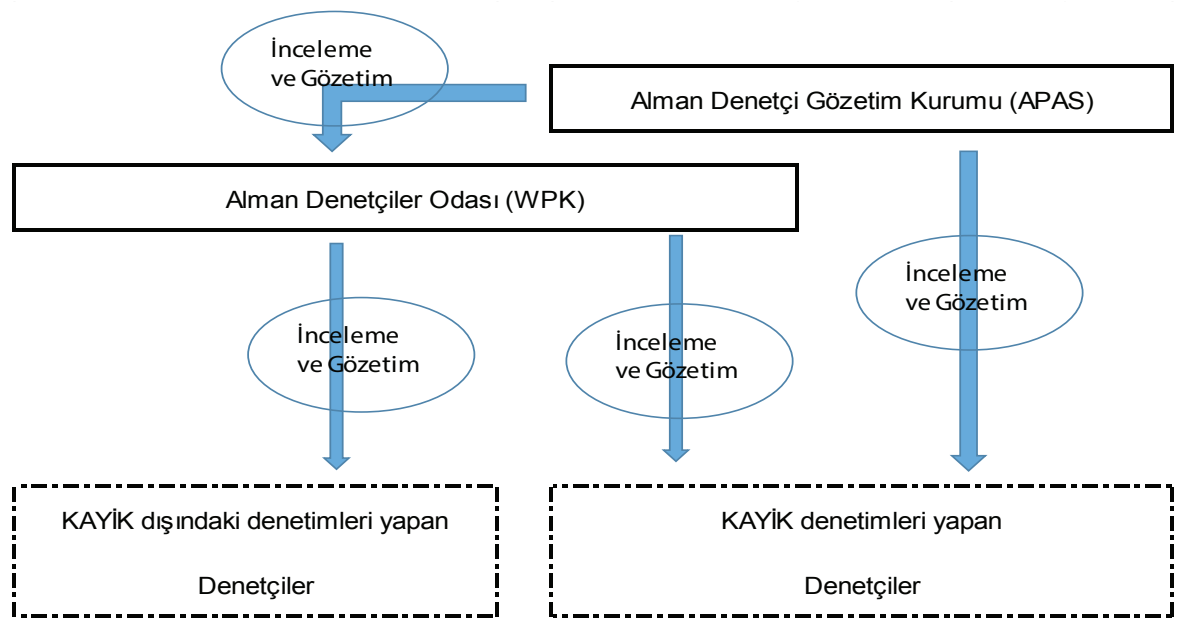

Şekil 2: Almanya'da Monitoring Sistemi ile Yapılan Gözetim ve İnceleme

\begin{abstract}
Almanya'daki Kalite Güvence Sistemi'nin karma model olarak kabul edilmesinin nedeni, meslek yapılanmasından bağımsız bir kamu kurumunun yaptığı üst gözetim (Monitoring) faaliyetinin yanı sıra, sistemde bir de Peer Review uygulamasına benzer bir uygulamaya yer verilmiş olmasıdır. Almanyadaki Peer Review uygulamasının Monitoring uygulamasından çok daha eski bir geçmişi vardır. İlk olarak 2000 yılında Denetçi Meslek Yasası’nda yapılan değişiklikle kalite güvence sistemi uygulamalarında önemli bir adım atılmış ve Peer Review uygulamasına benzer nitelikteki Kalite Kontrol Sistemi Denetimi yürürlüğe girmiştir. Meslek Yasası’na eklenen bir madde ile yasal zorunlu bağımsız denetim yürüten tüm meslek mensuplarının kalite kontrol sistemlerinin Meslek Odası tarafından dış denetime tabi tutulması hüküm altına alınmıştır. Yasa koyucu bu tür bir dış kalite kontrol uygulamasıyla iki amacın hedeflendiğini ifade etmiştir. Birincisi; dış kalite kontrollleri ABD'de uzun yıllardan beri uygulanmaktadır ve diğer Avrupa Ülkeleri’nde de benzer uygulamaların başladığı görülmüştür. 1998 yılında FEE’nin yaptığı bir araştırmada, o yıl itibariyle Almanya ve Avusturya hariç tüm üye ülkelerde dış kalite kontrol uygulamalarının başladığı görülmüştür. Denetim mesleğinin rekabet gücünü tehlikeye atmamak için böyle bir kalite güvence sisteminin uygulanmasının kaçınılmaz olduğu vurgulanmıştır. Ayrıca dış kalite kontrollerinin bir diğer hedefi; denetçi meslek faaliyetlerinin kalitesini yapılandırılmış bir dış gözetim/inceleme ile güvence altına almak, denetçilerin toplumsal alandaki itibarlarını ve denetçi mesleğine duyulan güven algısını kuvvetlendirmektir.
\end{abstract}


Yatırımcılar ve sermaye piyasalarının diğer katılımcıları için denetim raporlarının güvenilir olması büyük önem taşımaktadır, çünkü bu raporlara dayanılarak işletme hakkında görüş elde edilmektedir. Bu nedenle yasa koyucu kalite kontrollerine tabi olma zorunluluğunu bu denetimleri yapan denetçilerle sınırlandırmıştır.

Kalite kontrol sistemi denetimi, bağımsız denetim uygulayan meslek mensubunun (bağımsız denetçi veya bağımsız denetim şirketinin) denetim faaliyetlerinde uyguladı̆̆ı kalite kontrol sisteminin Meslek Odası tarafından atanan bir dış denetçi tarafından sistem denetimine tabii tutulmasıdır. Bu noktada, denetimi uygulayan kişinin de bir meslek mensubu olması Peer Review benzeri bir uygulama görüntüsü vermektedir. Ancak bu denetimde, denetimi uygulayacak uzmanın meslek mensubu tarafından seçilmiyor olması, akran denetiminden en belirgin farklı özelliğidir.

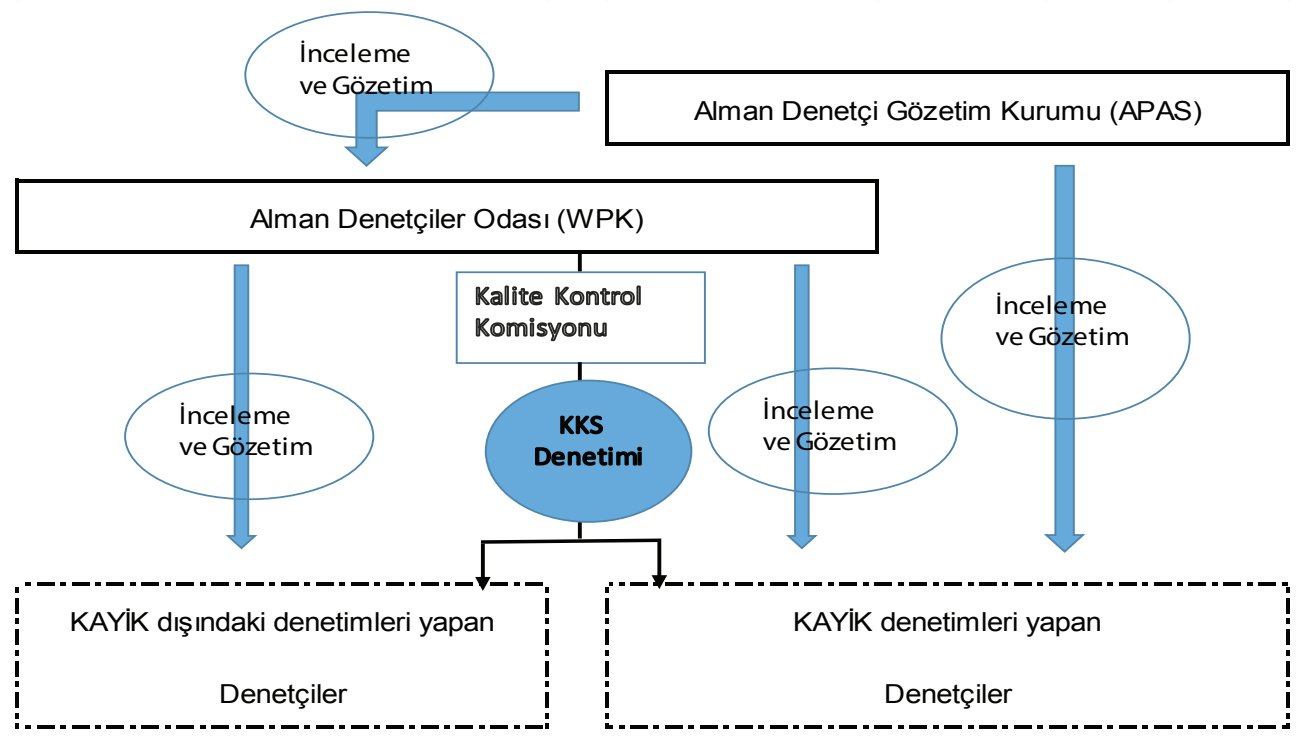

Şekil 3: Almanya'daki Kalite Güvence Sisteminin Bütünü-Karma Model

Şekil 3'de görüldüğü gibi, Almanya'da kalite güvence sisteminin iki önemli faktörü olarak Kalite Kontrol Sistemi Denetimleri (Peer Review) ve Alman Denetçi Gözetim Komisyonu Íncelemeleri (Monitoring) birlikte işlemekte ve hem Peer Review sisteminin hem de Monitoring sisteminin sağladığı faydaları birleştiren bir karma kalite güvence sistemi modeli ortaya çıkmaktadır.

Bu karma modelde sistemin önemli bir faktörünü oluşturan ve Meslek Odası eliyle yürütülen Kalite Kontrol Sistemi Denetimleri 2016 yılında büyük ölçüde revize edilmiş, yeniden düzenlenmiştir. Avrupa Birliği 8. Yönergesindeki değişiklikleri ulusal mevzuata aktarabilmek amacıyla yapılan bu değişiklikler sonucu Kalite Kontrol Sistem Denetimi uygulamalarının geldiği son durum bir sonraki bölümde açıklanacaktır. 


\section{Kalite Kontrol Sistemi Denetimi}

Avrupa Birliğỉnin 2014 yllında 8. Yönerge'de yaptığı değişiklikleri kendi ulusal mevzuatına geçirebilmek amacıyla Almanya, 2016 yılında Meslek Yasası̉ndaki Kalite Kontrol Sistemi Denetimine ilişkin hükümlerde önemli değişiklikler yapmıştır. Almanya’da kalite kontrol sistemi denetimine ilişkin yasal düzenlemeler Meslek Yasası madde 57a ila 57h'de ele alınmıştır. Söz konusu düzenlemelerin etkisini artırmak ve uygulanması hususunda açıklık ve netlik sağlamak amacıyla 2016 yılının Haziran ayında ayrıca bir tüzük yayınlanmıştır. Bunun yanı sıra, Denetçiler Enstitüsü’nün 140 numaralı "Denetimde Kalite Kontrolü” isimli denetim standardı da kalite kontrol incelemelerinin yürütülmesine ilişkin yeterli kabul edilebilecek gereklilikleri açıklamaktadır.

Denetçi Meslek Yasası̉na göre yasal zorunlu bağımsız denetim yapan meslek mensuplarının Kalite Kontrol Sistemi Denetimi'nden geçmeleri zorunludur. Almanyada yasal zorunlu olan denetimleri yapabilmek için Meslek Odası tarafından sicile "Bağımsız Denetçi” olarak kaydedilmek gerekmektedir. Bağımsız denetim görevi almak isteyen meslek mensubu (denetçi/denetim şirketi) bu talebini, "yıl içinde kaç denetim yaptı̆̆ı", "denetimi yapılan şirketlerin büyüklükleri", "kaç yıldan beri denetim yapıldığı" gibi bilgileri de içeren bir yazı ile beyan ederek, Meslek Odası'na başvurmaktadır. Meslek Odası bu beyan doğrultusunda meslek mensubunu bağımsız denetçi olarak sicile kaydeder. Bağımsız denetçi olarak sicile kaydedilen meslek mensubu, sicil kaydını takip eden üç yll içerisinde Kalite Kontrol Sistemi Denetimi’nden geçmelidir. Kalite kontrol sistemi denetimleri ileriki dönemlerde altı yılda bir tekrarlanmalıdır. Yasal zorunlu bağımsız denetimleri yürütmek isteyen denetçiler (bağımsız denetçiler/bağımsız denetim şirketleri) için kalite kontrol denetimi sürecine girmiş olmak zorunlu iken diğer meslek mensupları da isteğe bağlı olarak bu incelemeden geçebilirler.

Kalite kontrol sisteminin denetimi; bağımsız denetimde kalitenin sağlanması amacıyla, denetim sürecinde uygulanması zorunlu olan ve Meslek Yasası’nda belirlenmiş kalite güvence önlemlerinin gözden geçirilmesi/incelenmesi faaliyetidir. Denetçi Meslek Yasası’nda kalite kontrol sistemi denetimlerinin amacının, "denetim faaliyetlerindeki kalite sistemine ilişkin öngörülen tüm yasal ve mesleki düzenlemelerin uygulanmasını güvence altına almak” olduğu ifade edilmiştir. Meslek Yasası'nda etkin ve etkili bir denetimin nasıl yürütüleceği ve denetimde kalitenin sağlanması adına ne gibi önlemler alınacağı belirlenmiştir. Bu önlemler tüm denetçilerin denetim faaliyetlerinde göz önünde bulundurmak ve uygulamak zorunda olduğu, denetçinin iç kalite kontrol sistemine yönelik düzenlemelerdir. Ancak denetçinin, söz konusu bu kalite kontrol sistemini ne derece yeterli şekilde oluşturduğu, sistemin asgari gerekliliklerini uygulayıp uygulamadığı gibi hususların ayrıca incelenmesi gerekmektedir. Özellikle yasal zorunlu bağımsız denetim yapan denetçilerin/ denetim şirketlerinin kendi iç süreçlerindeki kalite kontrol sistemlerinin uygunluğu, yeterliliği ve etkinliğinin gözden geçirilmesi gerekmektedir. Denetçinin/denetim şirketinin iç kalite kontrol sisteminin ne zaman yeterli ve etkili olarak kabul edileceği ise hem Meslek Yasası'nda hem de Alman Bağımsız Denetim Standartları’nda tanımlanmıştır. Buna göre bir sistem, tüm yasa ve tüzüklerdeki düzenlemeleri yerine getiriyor ve bu şekilde denetim faaliyetini düzenli şekilde 
yürütüyor ise yeterlidir. Kalite kontrol sisteminin kuralları tüm denetim ekibi tarafından biliniyor ve günlük rutin çalışmalarında bu düzenlemeler dikkate alınıyor ve uygulanıyor ise sistem etkilidir. Kalite kontrol sistemi denetimlerinde ayrıca denetimde kullanılan araç ve personelin nitelik ve niceliğine, denetçi bağımsızlığına ilişkin kriterlerin sağlanıp sağlanmadığına yönelik görüş oluşmaktadır.

Kalite kontrol sistemi denetimlerinin işleyişi Meslek Yasası hükmünce Meslek Odası’na verilmiştir. Meslek Odası'nın bünyesinde kurulan Kalite Kontrol Komisyonu kalite kontrol sistemi denetimi süreci ile bağlantılı olan tüm koordinasyon ve gözetim süreçleri görevlerini üstlenmiştir.

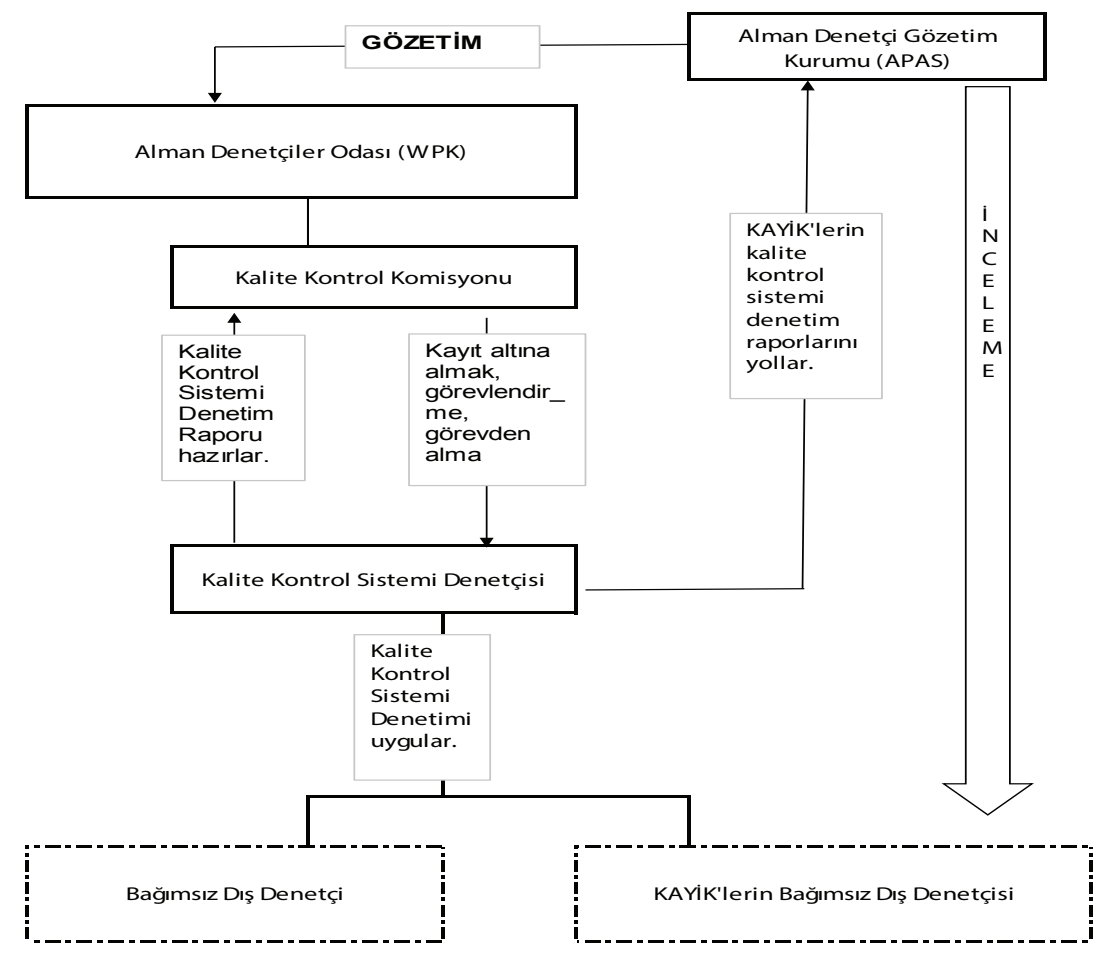

Şekil 4: Kalite Kontrol Sistemi Denetiminin İşleyiş Yapısı

Şekil 4'de Meslek Odası tarafından organize edilen kalite kontrol sistemi denetiminin işleyişine yönelik genel durum görülmektedir. Meslek Odası, odanın bir organı olarak kurulan "Kalite Kontrol Komisyonu”na bu sürece ait tüm yetki ve sorumlulukları devretmiştir. Kalite Kontrol Komisyonu da görevlendirdiği "Kalite Kontrol Sistemi Denetçileri” üzerinden, bağımsız denetçilerin kalite kontrol sistemlerinin denetlenmesi faaliyetini yürütmektedir. 


\section{Kalite Kontrol Sistemi Denetçisi}

Kalite kontrol sistemi denetimleri, sadece Kalite Kontrol Komisyonu'nda kaydı yapılmış Kalite Kontrol Sistemi Denetçisi (çalışmada bundan sonra KKSD olarak kısaltılacaktır) tarafından yürütülebilir. Özel olarak eğitimden geçen meslek mensupları (denetçi/denetim şirketleri) Kalite Kontrol Komisyonu'na kayıtları yapıldıktan sonra "Kalite Kontrol Sistemi Denetçisi” ünvanını almaktadır. Meslek mensupları (denetçi/denetim şirketleri) aşağıdaki şartları sağlamaları durumunda Komisyonda "Kalite Kontrol Sistemi Denetçisi (KKSD)" olarak kayıt altına alınmaktadır:

- bağımsız denetçi olmak ve en az üç yıl boyunca bağımsız denetim faaliyetlerinde çalışmış olmak,

- kalite güvence sistemlerinin incelenmesinde yetkinliğini kanıtlayacak özel bir eğitimden geçmiş olmak,

- son beş yıl içerisinde Meslek Yasası'nda tanımlanmış olan sorumluluk ihmallerinden hiç birini yapmamış olmak, mesleki sorumluluğa zarar veren eylemlerde bulunmamış olmak.

Meslek mensuplarının "Kalite Kontrol Sistemi Denetçisi (KKSD)" olarak atanabilmeleri için bağımsız denetçi ünvanına sahip olmaları gerekmektedir. Denetim şirketlerinde ise şirketin yasal temsilcisinin bağımsız denetçi olması şartı aranmaktadır. KKSD adayı yazılı veya elektronik ortamda hazırlanan bir dilekçeyle, yukarıdaki gereklilikleri yerine getirdiğine dair ispat niteliğinde belgelerle birlikte Kalite Kontrol Komisyonu'nda başvurusunu yapmaktadır.

Bağımsız denetçi, komisyonda KKSD olarak kayıtlanmadan önce en az üç yıl boyunca bağımsız denetim yapmış olmalıdır. Bu sürenin hesaplanmasında bağımsız denetim kapsamında yapılan her faaliyet, kalite güvence sistemine ilişkin yapılan her iş, uzmanlık alanını ilgilendiren her çalışma sayılmaktadır. Bağımsız denetçilerin KKSD olmak için geçmeleri gereken özel eğitimin niteliği ise Meslek Odası'nın yayınladığı bir tüzükle açıklanmıştır. Buna göre; en az 45 dakikadan oluşan 16 ders saatlik bir eğitim olmalıdır ve eğitim aşağıdaki konu başlıklarını içermelidir:

- Kalite Kontrol Sistemi Tanımı ve Yapısı,

- Kalite Kontrol Sistemi Denetçisinden Beklenenler,

- Kalite Kontrol Sisteminin Özellikleri,

- Kalite Kontrol Sistemi Denetiminin İşleyişi,

- Kalite Kontrol Sistemi Denetime İlişkin Raporlama.

Kalite Kontrol Komisyonu, eğitim içeriğinin yukarıda açıklanan ana başlıkları içerip içermediği ve belirtilen sürede olup olmadığı hususunda onay vermektedir. Komisyonun onayından geçmemiş eğitimler geçersiz kabul edilmektedir. Ayrıca Komisyon, eğitimin içeriğine ilişkin her türlü bilgi ve belgeyi eğitimi düzenleyen kurum ve eğitmenden talep etme ve eğitimleri yerinde inceleme hakkı ve yetkisine sahiptir. Eğitim düzenleyen kurumun en az bir öğretim üyesinin Kalite Kontrol Denetçisi olması zorunluluğu vardır. Kalite Kontrol Denetçisi adayının katıldığı özel eğitimin, Komisyona 
kayıtlanmak için başvurduğu tarihten en fazla üç yıl öncesine dayanması gerekmektedir. Üç yıldan daha eski bir dönemde alınmış eğitimler, başvuruda geçersiz sayılmaktadır.

Görüldüğü gibi, kendi de bağımsız denetçi olan meslek mensupları kalite kontrol sistemine ilişkin özel bir eğitiminden geçtikten sonra KKSD olarak atanabilmektedir. Bu düzenlemelerin amacı, sadece kalite kontrol sistemi hakkında teori ve pratikte bilgi sahibi deneyimli denetçilerin KKSD olarak görevlendirilmelerini sağlamış olmaktır.

KKSD olarak atanmak için gerekli olan şartların ileride ortadan kalkması durumunda Komisyon bu meslek mensuplarını kayıt dışına çıkarmaktadır. Ayrıca aşağıdaki durumlarda da KKSD kayıt dışına alınmaktadır:

- Bağımsız denetçi kaydı ortadan kalkarsa,

- Son üç yıl içerisinde yasal zorunlu bağımsız denetim yapmadıysa,

- Meslek Yasası̉nda tanımlanmış sorumluluk ihmalleri oluştuysa

- Son üç yll içerisinde Kalite Kontrol Sistemlerine ilişkin sürekli eğitimlere katılmadıysa.

Fiilen aktif olarak bağımsız denetim yapan ve "sürekli eğitim" kapsamında eğitim gören KKSD’ler görevde kalabilmektedir. Bu doğrultuda KKSD’ler için bir sürekli eğitim yükümlülüğü bulunduğu görülmektedir. KKSD, Kalite Kontrol Komisyonu’nun açtığı ya da Komisyon’un onay verdiği kurumların açtığı eğitimlere katılmalı ya da bu eğitimlerde öğretim görevlisi olarak görev almalıdır. Sürekli eğitim 45 dakikalık 24 ders saatinden daha az olmamalıdır. Sürekli eğitimler, mesleki alanda ortaya çıkan güncel gelişmeleri de dikkate alarak üç yllda bir yenilenmelidir.

Kalite kontrol sistemi denetiminin bağımsız ve tarafsız yürütülmesi adına da belirli önlemler alınmıştır. Buna göre; kalite kontrol sistemi denetimine tabi olacak bağımsız denetçi/bağımsız denetim şirketi ile KKSD arasında

- Finansal ya da kişisel bir bağ varsa,

- Tarafsızlığı ortadan kaldıracak durumlar mevcutsa,

- Ya da son üç yıl içerisinde bu tanımlanan ilişkiler oluşmuş ise

KKSD söz konusu bağımsız denetçinin/bağımsız denetim şirketinin kalite kontrol sistemi denetimi işini üstlenemez. KKSD, denetim işini üstlenmeden önce bağımsız denetçi/bağımsız denetim şirketi ile arasında çıkar çatışması yaratacak herhangi bir bağ olmadığına ilişkin bir Bağımsızlık Beyannamesi hazırlamalıdır.

Hem KKSD hem de ekibinde görev verdiği yardımcılarının süreç boyunca kendileriyle paylaşılan verilere ilişkin sır tutma ve saklama yükümlülüğü bulunmaktadır. Bu sır tutma yükümlülüğü, hem KKSD’nin denetlenen meslek mensubunun (bağımsız denetçinin/bağımsız denetim şirketinin) çalı̧̧ma kağıtlarına denetim süresince bakabilmesini hem de müşteri firmanın sırlarının açığa çıkmasını engellemek amacıyla getirilmiş bir düzenlemedir. Bağımsız denetçinin/ 
bağımsız denetim şirketinin müşteri firmaya karşı olan sır tutma yükümlülüğü ise bu durumda KKSD’ye karşı sınırlandırılmış olmaktadır. Çünkü bağımsız denetçi/bağımsız denetim şirketi, kalite kontrol sistemi denetiminde, müşteri firmanın denetimine ilişkin çalışma kağıtlarının hepsini KKSD ile paylaşmak zorundadır.

KKSD, yürüttüğü sistem denetiminden sonra buna ilişkin bir rapor hazırlayarak Kalite Kontrol Komisyonu'na sunmaktadir.

\section{Kalite Kontrol Komisyonu}

Kalite Kontrol Komisyonu, Meslek Odası'nın bir organıdır ve kalite kontrol sistemi denetimlerine ilişkin tüm hususlar onun yetki alanındadır. Komisyon üyeleri Yönetim Kurulu’nun teklifi üzerine Danışma Kurulu tarafından, en az üç yıl görevde kalmak üzere meslek mensupları arasından seçilmektedir. Komisyonun en az dokuz üyesi Kalite Kontrol Sistem Denetçisi olan meslek mensubu olmak zorundadır. Komisyon üyeleri bağımsızdır ve üçüncü kişilerin talimatlarına bağlı değildir.

Yukarıda da belirtildiği gibi Kalite Kontrol Komisyonu, KKSD’nin görevlendirilmesinden, yürüttügü sistem denetiminin gözetilmesine kadar geniş bir yelpazede yetki ve sorumluluk sahibidir. Meslek Yasası'nda Komisyonun görevleri şu şekildedir sıralanmıştır:

- Kalite kontrol sistemi denetimlerinin bir risk analizi çerçevesinde düzenlenmesi,

- KKSD’lerin kayda alınması,

- Kalite Kontrol Sistemi Denetim raporlarının teslim alınması ve değerlendirilmesi,

- KKSD’lerin gözetimi, görevlendirilmesi ya da görevden alınması hususlarında karar alınması,

- KKSD’lerin kayıt dışına alınması,

- Kalite kontrol sistemi denetimlerine ilişkin kararlara itiraz olması durumunda bu itirazların değerlendirilmesi.

Kalite Kontrol Komisyonu, kalite kontrol sistemi denetimlerine katılma hakkına sahiptir ve KKSD'den çalışma kağıtlarını ibraz etmesini talep edebilir. Kalite kontrol sistemi denetimine tabi tutulan meslek mensubunda (bağımsız denetçide/bağımsız denetim şirketinde) kalite kontrol sistemine ilişkin eksiklikler tespit edildiyse ya da kalite kontrol sisteminden kaynaklanan meslek kanunu ihlalleri varsa, Komisyon bu eksikliklerin giderilmesini isteyebilir ya da yeni bir denetim talep edebilir. Komisyonun eksikliklerin bir an önce giderilmesi kararı alması durumunda, denetlenen denetçi/denetim şirketi komisyon tarafından belirlenen sürede bu eksiklikleri giderir ve gecikmeksizin bir rapor hazırlar. Kalite Kontrol Komisyonu’nun talep ettiği önlemleri almayan denetçiler için 25.000 Euroya kadar ceza parası talep edilebilir. Para cezasına rağmen talep edilen önlemlerin zamanında ve eksiksiz şekilde alınmaması durumunda Bağımsız Denetçi kayıt 
dışına alınır. Kalite Kontrol Komisyonu ayrıca aşağıdaki durumlarda meslek mensubunun yasal bağımsız dış denetimleri yapabilmesi için gerekli olan kayda alma işlemini iptal edebilir:

- denetçi Komisyon tarafından belirtilen süre içerisinde kalite kontrol sistemi denetimine tabi olmazsa,

- denetçinin KKSD tarafından yapılan kalite kontrol sistemi denetiminde önemli ölçüde sakıncalar tespit edildiyse,

- Kalite kontrol sisteminin yetersiz olduğuna ve etkin olmadığına dair önemli eksiklikler tespit edildiyse.

Kalite Kontrol Komisyonu, kayda alma işlemini iptal etmeden önce APAK’a bildirmektedir. Burada vurgulanması gereken husus, bağımsız dış denetçinin kayıt dışına çıkarılması, Meslek Odası sicilinden çıkarılması anlamına gelmemektedir. Yine meslek mensubudur, ancak bağımsız dış denetim faaliyetlerini üstlenemez. Komisyon yeni bir denetim yapılmasını gerekli görmesi durumunda bunun için başka bir Kalite Kontrol Sistemi Denetçisini görevlendirebilir.

Kalite kontrol sisteminin denetime tabi olmasını isteyen bir meslek mensubu (bağımsız denetçi/ bağımsız denetim şirketi), KKSD’nin seçiminde yasal olarak kurallara bağlanmış işleyişe uymak zorundadır. KKSD görevlendirilmeden önce Komisyon'un onayı alınmalıdır. Denetlenecek olan meslek mensubu (bağımsız dış denetçi/bağımsız denetim şirketi) bu amaçla Komisyon’a üç KKSD adayı önermektedir. Önerilen her bir KKSD’nin bağımsızlık beyanı ibraz edilmelidir. KKSD, bu bağımsızlık beyanında denetlenecek meslek mensubu ile arasında çıkar ilişkisi yaratacak hiçbir bağlantının olmadığını, bağımsızlık ve tarafsızlığını zedeleyecek kısıtlamaların bulunmadığını teyit etmektedir. Komisyon'un önerilen KKSD adaylarının bir kısmını veya hepsini birden reddetme hakkı mevcuttur. Komisyon'un adayları reddetmesinde en belirgin etken KKSD adaylarının bağımsızlıklarına ilişkin şüphe oluşması durumudur. Komisyon'un tüm adayları reddetmesi durumunda, meslek mensubu yeniden üç aday belirleyerek bağımsızlık beyannameleri ile birlikte Komisyon'a sunar. Bu noktada, KKSD ile denetlenecek meslek mensubunun karşılaştırılabilir büyüklükte olmasının, Komisyon tarafından onay işleminin alınması hususunda avantaj yaratacağı söylenebilir. Böyle bir durumda KKSD ile denetlenecek meslek mensubu arasında benzer tecrübeler ve organizasyonel anlamda benzerlikler oluşacaktır.

KKSD, meslek mensubunun denetlenme talebini kabul etmeden önce, bağımsızlı̆̆ı ortadan kaldıracak herhangi bir bağlantının olmadığı konusunda emin olmalıdır. Ayrıca denetim teklifini ancak denetimi gerçekleştirebilmek için gerekli özellikli bilgi ve tecrübeye sahipse kabul edebilir. Özellikli bilgi ve tecrübe, örneğin belirli sektörlerde denetim yapan ya da IFRS'ye göre denetim yapan meslek mensuplarının kalite kontrol sistemlerinin denetlenmesinde gerekli olabilir. KKSD ayrıca denetim teklifini kabul etmeden önce Meslek Yasası gereği KKSD olarak atanabilme kriteri olarak talep edilen "kalite güvence sistemlerine ilişkin sürekli eğitim” programlarına katıldığını belgelemelidir. KKSD göreve atandıktan sonra ancak önemli bir neden oluşması durumunda görevden çekilebilir. Meslek Yasası'na göre bir KKSD’nin denetim görevinden geri çekilmesinin en birinci nedeni, bağımsızlı̆̆ı ortadan kaldıran etkenlerin oluşmasıdır. Böyle bir durumda, KKDS 
o ana kadar yürüttügü denetim faaliyetlerini ve görevden çekilmesine ilişkin nedenleri içeren bir rapor hazırlar ve denetlenen meslek mensubuna sunar. Meslek mensubu görevi devralan bir sonraki KKSD’ya bu raporu sunacaktır.

Kalite Kontrol Komisyonu, KKSD’nin denetimini yasal gerekliliklere uyarak yerine getirip getirmediği hususunda ayrıca gözlem ve incelemeler yapmakla yetkilidir. Bu haliyle Kalite Kontrol Komisyonu, KKSD ve Denetçi Gözetim Kurumu’nun yanında kalite güvence sisteminin üçüncü aktörü konumundadır.

Kalite Kontrol Komisyonu üyeleri Meslek Odası'nın Yönetim Kurulu ya da Danışma Kurulu gibi herhangi başka bir organında görev alamazlar. Bu düzenleme oldukça önemli ve yerinde bir düzenleme olmuştur. Bilindiği gibi bir Meslek Odası’nın ana görevlerinden biri, meslek mensuplarının görevlerini beklenen kalite ve titizlikte gerçekleştirmelerini sağlamak ve bu amaçla gerekli önlemleri almaktır. Bunun için en geçerli olan yol ise meslek mensupları üzerinde gözetim yapmaktır. Meslek Odası́nın gözetim görevi (Mesleki Gözetim) ile Kalite Kontrol Komisyonu üzerinden yapılan incelemelerin (Kalite Kontrol Sistemi Denetimi) organizasyonel ve idari anlamda tamamen birbirlerinden ayrılmaları, bağımsız denetçiler üzerinde yapılacak mesleki gözetimin gücünü artıracaktır.

Kalite Kontrol Komisyonu her yıl Denetçi Gözetim Kurumu'nun onayının ardından bir rapor hazırlamakta ve bu faaliyet raporunda kalite kontrol sistemi denetimlerinin sonuçlarını anonim şekilde açıklamaktadır. Komisyon’un yayınladığı bu rapor; o yıl içerisinde yürütülen bağımsız denetim faaliyetlerinde ne derece kaliteli iş yapılabildiği, hangi eksikliklerin olduğu, kalite kontrol sistemlerinde geliştirilmesi gereken yönlerin neler olduğu vb. hususlarda önemli bilgiler sunmaktadır. Bu bilgiler ışığında gerek Meslek Odası'nın gerekse Denetçi Gözetim Kurumu’nun denetimde kalite güvencesinin sağlanmasına ilişkin alacakları önlemler ve uygulamalar belirlenmektedir.

\section{Karma Modelin Türkiye Açısından Değerlendirilmesi}

Türkiye’de, bağımsız denetçilerin yürüttükleri denetim faaliyetlerine ilişkin bir üst gözetim kurumu olarak "gözetim ve incelemeler" yapmak, Kamu Gözetimi Muhasebe ve Denetim Standartları Kurumu (KGK)'nın yükümlülüğü altındadır. Kurum, - AB 8. Yönergesi’nin ön gördüğü - denetimde meslek yapılanmasının dışında "kamu gözetimi” yapacak bağımsız bir kuruma sahip olmak amacıyla kurulmuştur. Bakanlar Kurulu tarafından atanan 9 üyeden oluşmakta olan Kurum'un üyelerinin, atanmalarından önceki son 3 yılda; bağımsız denetim faaliyetinde bulunmamış, bir bağımsız denetim kuruluşunda yönetim kurulu üyeliği yapmamış veya bir bağımsız denetim kuruluşunca istihdam edilmemiş olması ya da doğrudan veya dolaylı olarak bir bağımsız denetim kuruluşu ile ortaklık ilişkisinin olmaması zorunludur. Bu düzenleme ile Kurul üyelerinin tamamen meslek mensupları dışından olması sağlanmaktadır. Ayrıca kurul üyeleri için muhasebe, finans, vergi, denetim ve hukuk alanlarından birinde en az on yıllık deneyim sahibi olmaları şartı aranmaktadır. Kurumun görevleri şu şekildedir: 
- Denetim standartlarını oluşturmak ve yayımlamak.

- Denetim faaliyetlerini üstlenebilecek denetçileri belirlemek ve yetkilendirmek,

- Denetçileri oluşturacağı resmi sicile kaydederek kamuya duyurmak,

- Denetçilerin denetim çalışmalarının, Kurumca yayımlanan standart ve düzenlemelere uyumunu gözetlemek ve denetlemek,

- Aykırılıkları saptanan denetçilerin faaliyet izinlerini askıya almak veya iptal etmek,

- Denetçilere yönelik sınav, yetkilendirme ve tescil yapmak, disiplin ve soruşturma işlemlerini yürütmek,

- Sürekli eğitim standartları ile mesleki etik kurallarını belirlemek.

Söz konusu görevler incelendiğinde, Alman Denetçi Gözetim Kurumu (APAS) ile en belirgin fark olarak, KGK’nın görev ve yetki alanının daha geniş olduğu görülmektedir. Almanyada denetime yönelik görevlerin tamamı Meslek Odası'na (WPK) aittir, APAS ise bu faaliyetlerin yürütülmesi sürecinde Meslek Odası (WPK) üzerinde kontrol ve gözetim yetkisine sahiptir. Bir diğer ifadeyle denetime ilişkin tüm faaliyetlerin, denetçilerin sicil kaydının yapılması, görevlendirilmesi, görevden alınması, sınavların düzenlenmesi, meslek mensuplarının faaliyetlerine ilişkin incelemelerin yapılması vb. Alman Meslek Odası'nın yetki ve görevleri arasındadır. APAS, Meslek Odası'nın faaliyetlerine yönelik inceleme ve gözetim yapmaktadır. APAS’ın doğrudan meslek mensupları üzerinde inceleme yapma hakkı sadece KAYİK denetimleri yapan denetçiler için geçerlidir. Şekil 5, denetimde kalitenin güvence altına alınması için uygulanan gözetim sistemlerini Türkiye ve Almanya açısından karşılaştırmaktadır. 


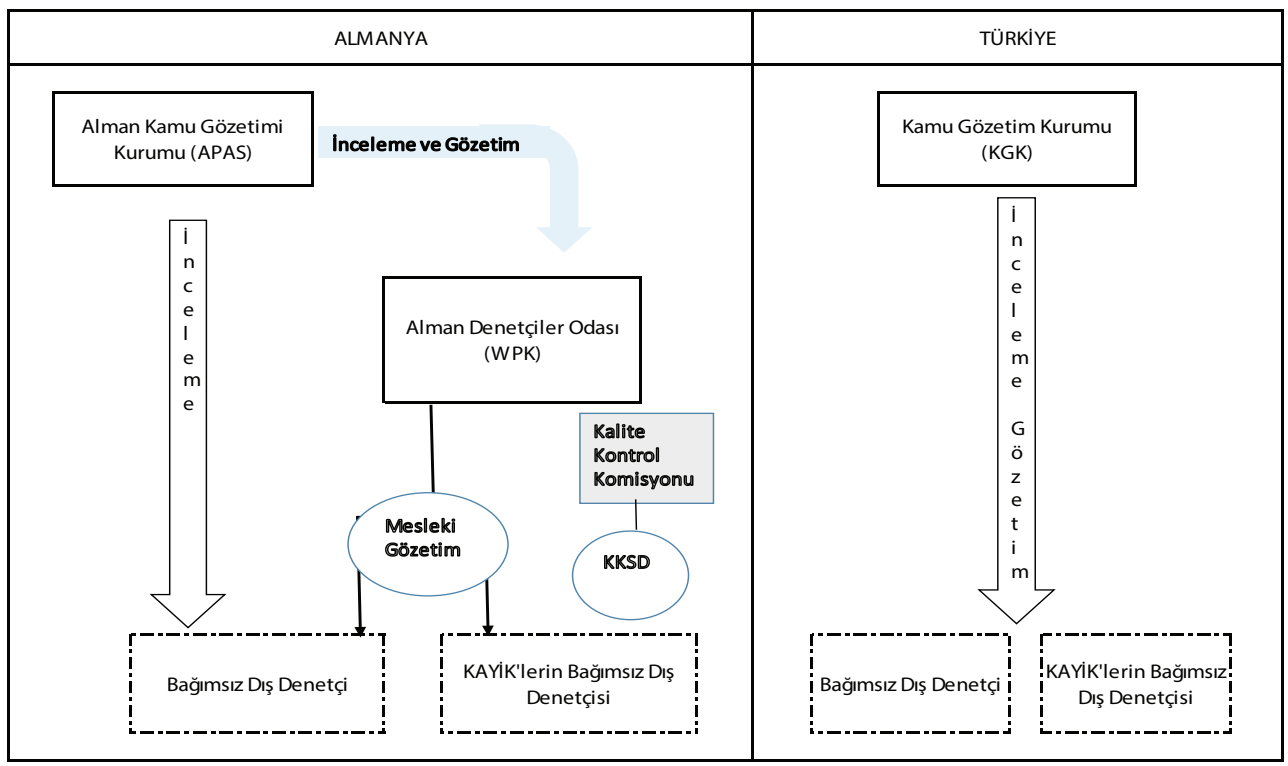

Şekil 5: Türkiye ve Almanya'daki Kalite Güvence Sistemlerine İlişkin Yapının Karşılaştırılması

KGK’nın bağımsız dış denetçiler üzerinde yapacağı inceleme ve denetimlerle ilgili düzenlemeler Bağımsız Denetim Yönetmeliğìnin 38. Maddesinde yer almıştır. Bu maddeye göre; KGK, oluşturacağı kalite güvence sistemi kapsamında, seçilmiş yeterli sayıda denetim dosyaları ve diğer bilgi, bildirim ve belgeler çerçevesinde denetim kuruluşlarını ve denetçileri incelemek ve denetlemekle görevlidir. Denetim kuruluşlarındaki inceleme ve denetimler; denetim kuruluşlarınca gerçekleştirilmiş denetim çalışmalarının mevzuat çerçevesinde gözden geçirilmesi ve bu kuruluşların faaliyetlerinin mevzuata uygunluğunun denetimi ile harcanan kaynakların nitelik ve niceliği, alınan denetim ücreti ve denetim kuruluşunun iç kontrol sistemi ile ilgili değerlendirmelerini kapsamaktadır. İnceleme sonuçları her yıl bir raporla kamuoyuna açıklanmaktadır. Almanya'da bağımsız denetimlerin kalitesine ilişkin inceleme, Meslek Odası'na bağlı Kalite Kontrol Komisyonu tarafından görevlendirilen KKSD’ler tarafindan yapilmakta ve bu Komisyon her yil bu kalite kontrol sistemi denetimlerinin sonucuna ilişkin rapor yayınlamaktadır. Alman Denetçi Gözetim Kurumu (APAS) ise, Meslek Odası'nın çalışmaları üzerinde yaptığı inceleme ve gözlem sonuçlarını ve ayrıca KAYİK niteliğindeki firmaların bağımsız dış denetçilerinin incelenmesinin sonuçlarını yıllık bir rapor ile yayınlamaktadır.

KGK, KAYİK’leri denetleyen denetim kuruluşlarında asgari üç yılda bir, diğerlerinde asgari altı yılda bir, denetçilerde ise Kurumca gerek görüldügünde inceleme ve denetim yapmaktadır. Almanya'da tüm bağımsız denetçilerin denetimlerinin, Meslek Odası’nın organı olan Kalite 
Kontrol Komisyonu’nun görevlendirdiği KKSD’ler tarafından altı yılda bir tekrarlanması gerekmektedir. Ayrıca KAYİK niteliğindeki firmaların bağımsız denetçilerinin denetimleri de Alman Denetçi Gözetim Kurumu (APAS) tarafından doğrudan incelemeye tabidir.

KGK, 2014 yılı ve 2015 yıllarında yaptığı kalite kontrol sistemi incelemelerinin sonuçlarını "Yıllık İnceleme Raporu” adı altında 2017 yılı Haziran ayında yayınlamıştır. Rapora göre; incelenen denetim dosyalarının \%84'ünde iç kontrollerin yeterli şekilde anlaşılmadığ ve başta kontrollerin test edilmesi, kontrol çevresi unsurlarının anlaşılması, iç kontrol sisteminin eksikliklerinin değerlendirilmesi olmak üzere iç kontrol sisteminin anlaşılmasına yönelik çalışma ve değerlendirmelerde eksikliklerin olduğu tespit edilmiştir. Ayrıca incelenen dosyaların \%68'inde, başta bağımsızlık, müşteri ilişkisinin ve denetim sözleşmesinin kabulü ve devam ettirilmesi ve denetimin kalitesine yönelik gözden geçirme olmak üzere kalite kontrol sistemine ilişkin eksiklikler olduğu görülmüştür. Kabul etmek gerekir ki, bunlar oldukça yüksek oranlar olup, ülkemizde bağımsız denetimde kalite kontrol sistemi oluşturulması ve sistemin işlerliğinin sağlanmasında halen büyük ölçüde eksiklikler olduğunu açık ve net şekilde ortaya koymaktadır. Kalite kontrol sistemlerinin etkinliğini artırmak ve bağımsız denetim faaliyetlerinin kaliteli şekilde yürütülmesini sağlamak adına acil önlemler alınması kaçınılmazdır.

Almanya'daki karma model, Meslek Odası'na da büyük sorumluluklar vermekte, bu şekilde denetimde kalitenin sağlanmasına ilişkin tedbirlerin çift koldan (Meslek Odası bir yandan Kamu Üst Gözetim Kurumu diğer yandan) alınmasını sağlamaktadır. Meslek Odası'nın yaptı̆̆ kalite kontrol sistemi denetimleri ile Denetçi Gözetim Kurumu’nun yaptığı denetimleri mükerrer yapılan denetimler olarak değil, tam tersi çift süzgeçten geçirmek gibi algılamak gerekmektedir. Özellikle Alman Meslek Odası’nın yaptı̆̆ı kalite kontrol sistemi denetiminden geçmemiş bağımsız denetçilerin kayıt dışına alınmasının, bir diğer ifadeyle faaliyet izinlerinin geri alınmasının, bağımsız denetçilerin kendi kalite kontrol sistemlerine vereceği önemi büyük ölçüde artıracağı kabul edilmelidir. Ancak Almanya'daki karma modelin Türkiyede uygulanabilmesi için sistem açısından mevcut olan farkların öncelikle ortadan kalkması gerekmektedir. Almanya'da denetime ilişkin her türlü faaliyet (denetçilerin sınavlarının yapılması, denetçilerin görevlendirilmesi, görevden alınması, faaliyet izinlerinin iptali, denetim standartlarının hazırlanması vb.) Meslek Odası'nın görev ve yetki kapsamındadır. Denetçi Gözetim Kurumu'nun ise doğrudan Meslek Odası üzerinde inceleme ve gözetim yapma hakkı bulunmaktadır. Türkiye'de KGK'nın tüm bu yetki ve görevleri kendi bünyesinde toplaması, hem iş yükünü artırmakta hem de mevcut kadrosuyla tüm bu görev ve sorumlulukları yerinde getirmede sıkıntı yaşanmasına neden olmaktadır. Nitekim Yıllık İnceleme Raporu’nda çıkan “incelenen firmaların \%68'inde kalite kontrol sistemlerinin yetersiz olduğu” sonucu, denetçilerde kalite kontrol sistemi anlayışının yerleşmesi için çok daha fazla çalışma yapılması gerektiğini ortaya koymaktadır. TÜRMOB ve KGK'nın iş birliği çerçevesinde oluşturulacak bir karma kalite güvence sistemi bu yönde atılacak önemli bir adım olacaktır. 


\section{Sonuç}

Almanyada bağımsız denetim faaliyetlerinde kalite güvencesinin sağlanması adına oluşturulan sistem, Meslek Odası ve Kamu Gözetimi Kurumu'nun ortak çalışmasına dayanan karma bir modeldir. Kalite güvence sisteminin iki önemli elementini oluşturan Kalite Kontrol Sistemi Denetimleri (Peer Review) ve Alman Denetçi Gözetim Komisyonu İncelemeleri (Monitoring) birlikte işleyen ve bu durumuyla hem Peer Review sisteminin hem de Monitoring sisteminin sağladığ faydaları birleştiren bir kalite güvence sistemi modeli oluşturmuştur. Bu modelde sistemin önemli bir faktörünü oluşturan ve Meslek Odası eliyle, ancak bağımsız bir komisyon tarafından yürütülen Kalite Kontrol Sistemi Denetimleri 2016 yılında büyük ölçüde revize edilmiş, yeniden düzenlenmiştir. Avrupa Birliği 8. Yönergesindeki değişiklikleri ulusal mevzuata aktarabilmek amacıyla yapılan bu değişiklikler sonucu, kalite kontrol sistemlerini denetletmek tüm bağımsız denetçiler için zorunlu hale gelmiştir. Bu düzenleme kalite kontrol sistemine verilen önemi artırmak ve kalite kontrol sisteminin işlerliğini artırmak adına faydalı sonuçlar yaratmıştır.

Türkiye’de KGK’nın yaptığı inceleme faaliyetlerinin sonucunu yayınladığı "Yıllık İnceleme Raporu”, ülkemizde bağımsız denetimde kalite kontrol sistemi oluşturulmasında ve sistemin işlerliğinin sağlanmasında halen büyük ölçüde eksiklikler olduğunu açı ve net şekilde ortaya koymaktadır. Bu doğrultuda, KGK’nın bağımsız denetçiler üzerinde yaptığı incelemelerin yanında, Meslek Odası üzerinden organize edilecek bağımsız bir "kalite kontrol sistemi denetleme” mekanizmasının oluşturulması büyük ölçüde fayda sağlayacaktır.

\section{Kaynakça}

Alman Ticaret Kanunu (Deutsches Handelsgesetzbuch)

Avrupa Birliği Yönergesi Nr. 537/2014 (Verordnung (EU) Nr. 537/2014 Des eurpäischen Parlaments vom 16. April 2014)

Bağımsız Denetim Yönetmeliği, 26.12.2012

Denetçi Gözetimi Reform Kanunu (Abschlussprüferaufsichtsreformgesetz - APAReG), 31 Mart 2016.

Denetçi Meslek Yasası (Wirtschaftsprüferordnung)

Uzay, Ş. (2006). Denetçilerin Denetiminde Yeni Bir Model Olarak Kamu Gözetim Kurulu ve Türkiye’de Uygulanabilirliği, WCAE, “The 10th World Congress of Accounting Educators \& The 3rd Annual International Accounting Conference", 9-11 Kasim 2006.

660 Sayılı KHK, Kamu Gözetimi, Muhasebe ve Denetim Standartları Kurumunun Teşkilat ve Görevleri Hakkında Kanun Hükmünde Kararname, 2 Kasım 2011. 